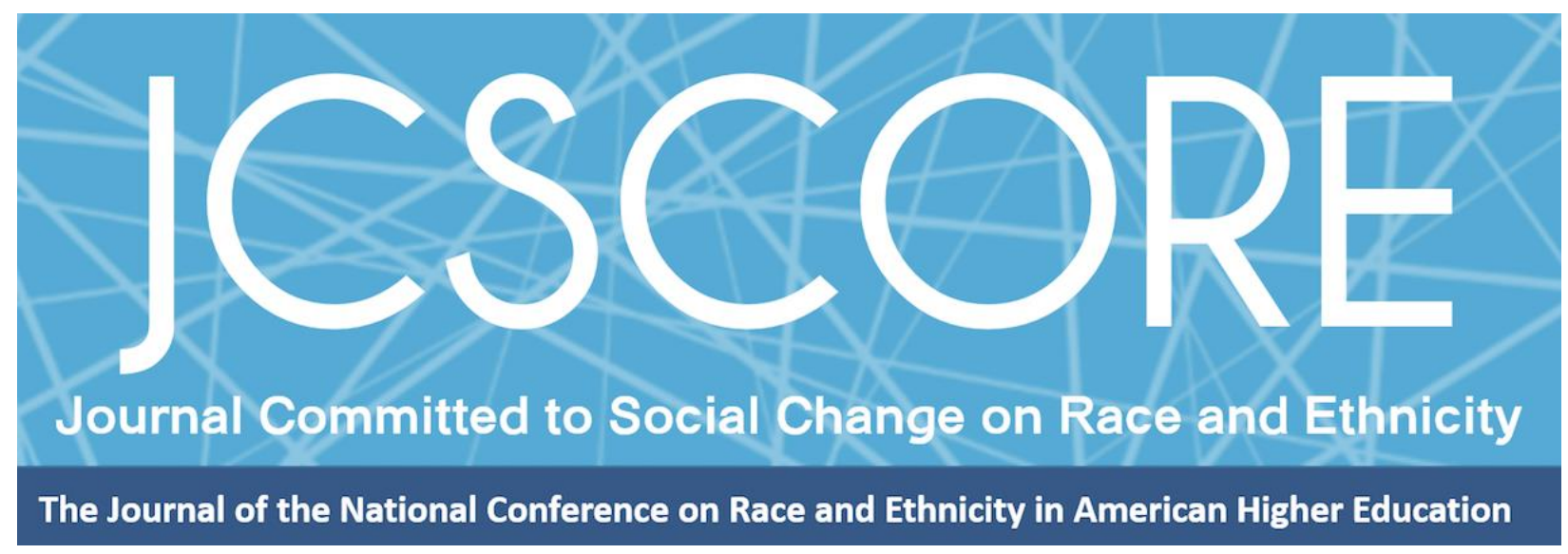

\title{
CENTERING QUEER LATINX/A/O EXPERIENCES AND KNOWLEDGE: GUIDELINES FOR USING JOTERÍA STUDIES IN HIGHER EDUCATION QUALITATIVE RESEARCH
}

\author{
Roberto C. Orozco \\ Rutgers University \\ Sergio Gonzalez \\ Claremont Graduate University \\ Antonio Duran \\ Auburn University
}

Journal Committed to Social Change on Race and Ethnicity

Volume 7, Issue 1| 2021

\section{Copyright and Open Access}

(C) 2021 Roberto C. Orozco, Sergio Gonzalez, Antonio Duran

\section{(c) (i) (2)}

This work is licensed under a Creative Commons Attribution-NonCommercial-ShareAlike 4.0 International License. Permission of the authors is required for distribution and for all derivative works, including compilations and translations. Quoting small sections of text is allowed as long as there is appropriate attribution and the article is used for non-commercial purposes.

The Journal Committed to Social Change on Race and Ethnicity (ISSN 2642-2387) is published by the National Conference on Race and Ethnicity (NCORE), a production of the University of Oklahoma, in partnership with the University of Oklahoma Libraries. 


\title{
Centering Queer Latinx/a/o Experiences and Knowledge: Guidelines for using Jotería Studies in Higher Education Qualitative Research
}

\author{
Roberto C. Orozco \\ Rutgers University \\ Sergio Gonzalez \\ Claremont Graduate University \\ Antonio Duran \\ Auburn University
}

\begin{abstract}
The landscape of higher education research and practice on Queers of Color (QoC) is increasingly offering possibilities of research paradigms and frameworks that best articulate and capture the unique experiences of race, ethnicity, gender, and sexuality. And, as research on queer Latinx/a/o people in higher education increases, researchers and scholars need to utilize frameworks that attend to this community. Notably, Jotería Studies is a framework that centers the material realities of queer Latinx/a/o people (Hames-García, 2014). Jotería Studies as a research paradigm shifts the possibilities to intentionally speak to the experiences of the queer Latinx/a/o community. Therefore, the purpose of this manuscript is to offer guidelines for qualitative researchers to use Jotería Studies to study topics of higher education. Consequently, using these guidelines assist in examining the ways in which queer Latinx/a/o people are structurally marginalized in ways that speak to the intersections of race, ethnicity, gender, and sexuality.
\end{abstract}

The landscape of higher education research and practice on Queers of Color (QoC) is increasingly offering possibilities of research paradigms and frameworks that best articulate and capture the unique experiences of race, ethnicity, gender, and sexuality (Duran \& Jones, 2020; Johnson \& Javier, 2017; Orozco \& Pérez-Felkner, 2018). Of note, Lange et al. (2019) assert the need to "theorize liberation through queer and trans epistemologies" (p. 512) from their analysis of a decade-long repository of queer research in higher education. Research on QoC in higher education in the last decade examine the identity development of Queer Students of Color (QSOC), 
Journal Committed to Social Change on Race and Ethnicity | Volume 7, Issue 1 | 2021

interrogate how QoC navigate oppressive structures espoused by institutions of higher education, and investigate the ways QoC build sites of resistance and resiliency through queer kinships. Although these strides exist, the opportunity remains to use knowledge, theory, and praxis from academic disciplines outside of higher education to move forward a continuous research agenda centered on QoC knowledge and experiences.

For this reason, scholars who examine the social position and structural marginalization of QoC in higher education bring in several critical frameworks at the intersections of race, ethnicity, gender, and sexuality. These include but are not limited to Muñoz's (1999) Disidentifications to examine the performance of racialized queerness, Johnson's (2001) Quare Theory/Studies to position the narratives of queer Black people, Ferguson's (2004) Queer of Color Critique as an analysis of the regulation of Black "non-heteronormativity" (p. 17), in addition to Black and Lesbian Chicana/Latina feminist frameworks such as Anzaldúa's (1987) Borderlands and Crenshaw's (1989) Intersectionality. The aforementioned frameworks originate from communities historically overshadowed and as research on QoC increases, scholars need to utilize frameworks that attend to this community. In alignment with Queer of Color frameworks, several queer Latinx/a/o scholars, practitioners, and activists' position Jotería Studies as an analytic that propels a more nuanced understanding of Latinx/a/o people. Jotería Studies is a framework that centers the narratives and experiences of queer Latinx/a/o people (Hames-García, 2014). Therefore, Jotería Studies as a research paradigm shifts the possibilities to intentionally speak to the experiences of queer Latinx/a/o community. 
Journal Committed to Social Change on Race and Ethnicity | Volume 7, Issue 1 | 2021

Respectively, the purpose of this manuscript is to offer guidelines for qualitative researchers to use Jotería Studies to study topics of higher education. In other words, we offer considerations for scholars hoping to mobilize Jotería Studies in their scholarship. These guidelines transcend outside of the researcher's commitment to using critical theory such as Jotería Studies and is a call for scholars, practitioners, and gatekeepers such as journal editors and conference proposal reviewers to intentionally engage how we conceptualize queer Latinx/a/o experiences in higher education. Though there exists an increasing number of studies on queer Latinx/a/o people in higher education (e.g., Duran \& Pérez, 2017, 2019; Duran et al., 2019; Eaton \& Rios, 2017; Orozco \& Pérez-Felkner, 2018; Peña-Talamantes, 2013a, 2013b; Rios \& Eaton, 2016; Tijerina Revilla, 2009, 2010), few studies name Jotería and Jotería Studies as a framework. Rather than offering new research methodologies, epistemologies, and theories, we build on the work of scholars who engage Jotería Studies to integrate their work into higher education scholarship (e.g., Alvarez Jr. \& Estrada, 2019; Bañales, 2014; Calvo-Quíros, 2014, Hames-García, 2014; Pérez, 2014b; Tijerina Revilla \& Santillana, 2014). Consequently, these guidelines assist to examine the oppressive realities queer Latinx/a/o people face due to the structures of race, ethnicity, gender, and sexuality among other social markers of identity.

\section{Queer of Color Mobilization in Higher Education}

The scholarship on the interconnectedness of race, ethnicity, gender, and sexuality among queer people in higher education necessitates frameworks that intimately capture the nuances of this population (Lange et al., 2019). Over the last twenty years, scholars of QoC in higher education continue to underscore the need to 
Journal Committed to Social Change on Race and Ethnicity | Volume 7, Issue 1 | 2021

interrogate structures that have material consequences for individuals who navigate the reality of a minoritized racial, ethnic, and sexuality identity. For example, scholars have investigated how Black students navigate and negotiate issues of race, ethnicity, gender, and sexuality (Johnson \& Quaye, 2017; King, 2011; McGuire et al., 2017; Means, 2017; Means et al., 2018; Patton \& Simmons, 2008; Squire \& Mobley Jr., 2015). Other scholars examined queer race pedagogy, bullying, identity development, leadership, and activism of QSOC within higher education (Duran \& Jones, 2020; Miller \& Vaccaro, 2016; Misawa, 2010; Vaccaro \& Mena, 2011). Researchers like Chan (2017) have also examined masculinity with queer Filipino college men.

Similarly, the scholarship on queer Latinx/a/o people, primarily focused on college students, continues to increase (Duran \& Pérez, 2017; Duran et al., 2019; Eaton \& Rios, 2017; Orozco \& Pérez-Felkner, 2018; Peña-Talamantes, 2013a, 2013b; Tijerina Revilla, 2009, 2010). Education and higher education scholars have also examined experiences of undocuqueer people as a focus on transnational and (im)migrant narratives (Cisneros \& Gutierrez, 2018; Cisneros \& Bracho, 2019). Notably, Jotería scholars have discussed the oppressive realities that queer Latinx/a/o face as a result of white supremacy and settler colonialism (Hames-García, 2014) while also highlighting their resilience (Pérez, 2014a). Given the growing scholarship on queer Latinx/a/o people in higher education, we argue for using research frameworks, like Jotería Studies, well-positioned to contribute to higher education scholars and practitioners understanding of queer Latinx/a/o people.

Jotería Studies is beginning to gain traction in the field of higher education and applied to examine the intricacies of queer Latinx/a/o people in postsecondary 
Journal Committed to Social Change on Race and Ethnicity | Volume 7, Issue 1 | 2021

institutions (Duran et al., 2020). As such, the guidelines throughout this manuscript offer an introspective opportunity for individuals who are interested in building knowledges and practices central to queer Latinx/a/o people.

\section{Defining Jotería Studies}

We begin this section by acknowledging the language we use in relation to gender. We use the term Latinx/a/o as a way to disrupt gender binary assumptions (Salinas \& Lozano, 2019). We acknowledge the use of Latinx by trans and gender nonconforming individuals as a way to unsettle gender and at times queerness (Lopez, 2018). We want to be explicit that we are not popularizing Latinx/a/o but rather offer one of many ways that folks use language to name themselves and their communities (Salinas, 2020). And, while contentions still exist about the way Latinx, much like Latine (Milian, 2020), Latinu or Latin* (Salinas, 2020), translates or is understood by others, we are cognizant that as three cisgender individuals who use Latinx/a/o from our position as scholars, our stake, like other scholars, in the discourse on Latinx, comes from privileged material realities of gender. As such, we invite others to contend with what stake they have, in terms of what they stand to lose or gain, in the conversation on whether to use or not to use Latinx.

Similar to our use of Latinx/a/o, how individuals and communities elect to name their realities is important (Salinas, 2020). Therefore, the utility of Jotería to name racialized queerness for queer Latinx/a/o people is an intentional and conscious act. As Bañales (2014) notes, "Jotería is a political project that seeks to reconfigure historically and socially negative understandings of an identity [gender and sexuality] that has been used in colonizing ways" and that seeks to challenge Western hegemony (p. 160). 
Journal Committed to Social Change on Race and Ethnicity | Volume 7, Issue 1 | 2021

Thus, Jotería is both a social marker of identity of sexuality often compounded with gender and an ontological project of knowledge and performance rooted in racialized queerness (Hames-Garcia, 2014). Gender is an important aspect of Jotería given the conflation of performing gender in non-normative ways with sexuality. Respectively, scholars, from fields such as Chicanx/a/o and Latinx/a/o Studies, Women's, Gender, and Sexuality Studies, and Communication Studies, who examine queer Latinx/a/o subjects, or Jotería, have developed a field of Jotería Studies. Much more than examining the narratives and social arrangements of queer Latinx/a/o people, Jotería Studies serves as a response to heteronormative spaces that continue to espouse notions of Western hegemony with respect to race, ethnicity, gender, sexuality, among other forms of oppressed identities and ways of being (Bañales, 2014; Duran et al., 2020; Hames-Garcia, 2014).

\section{Our Interest in Jotería Studies}

Before introducing the guidelines, we constructed for higher education scholars interested in using Jotería Studies in their scholarship, we first articulate what drew us to this body of scholarship. Discussing our own journeys sets a foundation for these guidelines.

Roberto's positionality is informed by his identities as a queer Chicano/Latino cisgender man who grew up in lowa to a working-class Mexican family. His work has primarily centered Jotería Studies as a central aspect of understanding the experiences and identity development of queer Latinx/a/o student activists. In addition to his scholarship, his professional experience lent itself to connecting theory and practice through his work with Queer Student of Color activists at a Minority-Serving Institution 
Journal Committed to Social Change on Race and Ethnicity | Volume 7, Issue 1 | 2021

(MSI). Roberto is committed and accountable to interrogating the ways queer Latinx/a/o college students resist systematic oppression while simultaneously building queer kinships rooted in healing and love.

Sergio writes from the core of who he is: joto, Latinx, feminist, hijo de a firstgeneration Madre and Mexican Immigrant Padre, jotería scholar, activist. As Lorde (2007) states, "I have come to believe over and over again that what is most important to me must be spoken, made verbal and shared, even at the risk of having it bruised or misunderstood" (p. 40). For this reason, his connection to jotería derives from his experiences navigating the Ivory Tower and trying to understand where he can exist within that space. As a scholar/activist, Sergio focuses on co-creating counternarratives of queer Latinx/a/o individuals within higher education.

Antonio identifies as a queer Latino cisgender man who comes from a workingclass background. As a scholar, he has long been committed to centering the experiences of queer Latinx/a/o people in postsecondary settings. Specifically, he came to Jotería Studies recognizing that there was a need to use theoretical frameworks that were specific to Latinx/a/o populations. Notably, Antonio is passionate about exposing how heterosexism, trans oppression, and racism shapes the lives of queer Latinx/a/o individuals while at the same time, underscoring how these groups are agentic in the face of these oppressive systems.

\section{Using Jotería Studies in Higher Education Research}

As the field of higher education increasingly calls on researchers to think critically and intentionally of their research designs, scholars centering the lives of queer Latinx/a/o people in postsecondary settings have the capacity integrate Jotería Studies 
Journal Committed to Social Change on Race and Ethnicity | Volume 7, Issue 1 | 2021

through each step of the research process. In the following section, we offer several guidelines for researchers, scholars, reviewers, and editors as an introduction to using Jotería Studies in studies on queer Latinx/a/o people in higher education. Importantly, undergirding all of these guidelines is a self-reflective practice in which researchers must acknowledge how their own identities, backgrounds, and experiences inform how they use Jotería Studies. Additionally, these are by no means rigid and exhaustive guidelines but ones that we hope elucidate critical thoughts and questions in conducting research on the developments of race, ethnicity, gender, and sexuality.

\section{Guideline 1: Centering the Voices and Knowledge of Queer Latinx/a/o People}

Several studies illuminate the experiences of queer Latinx/a/o people in higher education (Duran \& Pérez, 2017; Orozco \& Pérez-Felkner, 2018; Peña-Talamantes, 2013b; Tijerina Revilla, 2009). What this area of scholarship acknowledges, and honors, is that the Latinx/a/o community is diverse, consisting of different ethnicities, racial identifications, and other salient identities like sexuality and gender that influences how individuals experience their Latinx/a/o identity (Nuñez, 2014). Because Jotería Studies scholars posit an undoing of Jotería as a simplistic notion of identity (Hames-García, 2014; Muñoz, 1999), it is important for researchers and scholars to move beyond experiences with social identities but to also think about the ways in which queer Latinx/a/o people perform a queer Latinx/a/o consciousness. As such, Jotería Studies offers a way to reimagine these social identities and dive into a decolonizing collective consciousness and movement (Tijerina Revilla \& Santillana, 2014; Bañales, 2014). As Rodríguez (2003) stated, "Identity, therefore, is not merely a response to culturally defined differences, but is continually engaged in unpacking the stream of paradoxes 
Journal Committed to Social Change on Race and Ethnicity | Volume 7, Issue 1 | 2021

and contradictions that inform the subject's relationship to other subjects and the discourses that surround them" (p. 6). For this reason, the first guideline we offer is to center the voices and knowledge of queer Latinx/a/o people throughout the research design process.

Consequently, scholars of Jotería Studies adjacently build from frameworks that bring forth structures of race and ethnicity such as Critical Race Theory (CRT), Black Feminist Thought (BFT), Chicana Feminism, and other Women of Color feminist standpoints (Bernal, 1998; Collins, 1991; Crenshaw, 1989; Ladson-Billings \& Tate, 1995). These theories speak to the intersections of identities while simultaneously interrogating structures of oppression. Furthermore, the structures that come into play for queer Latinx/a/o people is the "lived legacies of colonialism, racism, xenophobia, homophobia, sexism, and heterosexism" (Hames-García, 2014, p. 136). Hames-García and Martínez (2011) assert that queer Latinx/a/o focused research "complements and overlaps with the groundbreaking work of lesbians of color and critical race theorists as well as queer theorists and gay and lesbian studies scholars" (p. 9). These frameworks illustrate the need to center the existence, lived experiences, and meaning making of the subject matter, in this case, queer Latinx/a/o people. Building alongside frameworks such as Quare Theory and Queer of Color Critique, "jotería has a cultural, linguistic, and political specificity" (Alvarez Jr. \& Estrada, 2019, p. 683) to honor queer Latinx/a/o people.

In order to center the voices of queer Latinx/a/o people and communities, we must interrogate how knowledge production is constructed in education and how it often excludes the very people they intentionally marginalize. By centering the knowledge of 
Journal Committed to Social Change on Race and Ethnicity | Volume 7, Issue 1 | 2021

queer Latinx/a/o people, Aguilar-Hernández (2020) actively "frames race and sexuality as inseparable for Queers of Color, as one way to enact an intersectional pedagogy that is anti-racist, anti-heterosexist, and anti-oppressive" (p. 1). How queer Latinx/a/o people name their identities is important in centering their voices and knowledge in the research process. It is also important to explicitly name how queer Latinx/a/o people build physical and imagined sites of resistance, knowledge production, and social change among their own communities including with other queer Latinx/a/o people (Duran et al., 2019; Tijerina Revilla, 2010). Therefore, using Jotería and Jotería Studies can elicit possibilities rooted in a being and doing of a queer Latinx/a/o identity.

\section{Guideline 2: Attending to a Jotería Studies Genealogy}

Hames-García (2011) argued that theorizing the experiences of QoC must go beyond the engrained history of queer theory as the starting point for understanding racialized queerness. Most formative texts on queer theory were published in the early 1990s but Queer of Color writers, academics, and activists were articulating a queer of color consciousness prior to this (e.g., Gloria Anzaldúa, Audre Lorde, Cherrie Moraga, Barbara Smith) (Hames-García \& Martínez, 2011). Similarly, Jotería and Jotería Studies has an extensive history of engaging race, ethnicity, and sexuality of queer Latinx/a/o people. In particular, Jotería Studies offers an interdisciplinary approach from the fields of Performance Studies, Chicanx/a/o Studies, Latinx/a/o Studies, and Gender and Sexuality Studies (Alvarez Jr. \& Estrada, 2019). Therefore, the second guideline intentionally attends to the interdisciplinary genealogy of Jotería Studies.

It is important to position the history of queer Latinx/a/o people in relation to survival and resistance towards oppressive structures of race, ethnicity, gender, 
Journal Committed to Social Change on Race and Ethnicity | Volume 7, Issue 1 | 2021

sexuality among other valid and real concerns like immigration histories. Texts like Moraga and Anzaldúa's (1981) This bridge called my back: Radical writings by Women of Color, Moraga's (1983) Loving in the war years: Lo que nunca paso por sus labios, and Anzaldúa's (1987) Borderlands/La Frontera: The new mestiza provides a critical foundation to formulate the bounds of race, ethnicity, gender, and sexuality, particularly for queer Latinx/a/o people. Each one of these texts encompasses an analysis of the authors' own personal experience as lesbian Chicanas, as well as the consequences and possibilities of naming this reality. Like the previous text, Rodríguez (2003) also engaged queer Latinidad as a discursive space to create "new bodies of knowledge" ( $p$. 6) that speak to the history of queer Latinx/a/o people. As such, Jotería Studies is a site of recovering and remembering queer memories and experiences for queer Latinx/a/o people. In Cruising Utopia, Muñoz (2003) positions queer memory as a framework of possibility that exist in queering identity of race and ethnicity and enacting queer performativity. Consequently, several scholars and authors who speak to and about queer Latinx/a/o narratives assert the need to think beyond what is known and seen to be queer as there exists an untapped world of possibility for queer Latinx/a/o people beyond the confines of social markers of identity.

It is also vital to engage the curated Jotería Studies dossier in Aztlan: A Journal of Chicano Studies to integrate more recent works that account for the genealogy of Jotería and Jotería Studies (Hames-García, 2014). To begin, Hames-García (2014) asserted Jotería is more than a social identity, but rather, it encompasses the multiplicity of acting on a Jotería consciousness. Likewise, within the dossier Pérez (2014b) provides a foundation for using epistemologies rooted in Jotería and Jotería Studies. 
Journal Committed to Social Change on Race and Ethnicity | Volume 7, Issue 1 | 2021

Identifying and performing Jotería allows for building on a historicized remembrance and uncovering of queer Latinx/a/o subjectivities. Consequently, agency of queer Latinx/a/o people is important in conducting research from a Jotería Studies perspective. Using Jotería Studies offers epistemologies and modes of knowledge production that centers queer Latinx/a/o narratives and realities.

As important is the way Jotería Studies challenges the negative stereotypes and tropes of hopelessness or passivity of queer Latinx/a/o people (Pérez, 2014a). Several scholars focus on the ways queer Latinx/a/o build communities of love and hope as a way to thrive rather than survive, although survival still remains a part of the larger discourse on queering racialized realities (Calvo-Quíros, 2014; Tijerina Revilla \& Santillana, 2014). Calvo-Quíros (2014) held onto healing and love as affirmations of a Jotería identity and praxis. Tijerina-Revilla \& Santillana (2014) also provided specific tenets of building out a Jotería identity and consciousness. Furthermore, Pérez (2014a) offered an epistemology rooted in the mariposa (butterfly) as a symbol of resistance and survival for queer Latinx/a/o people and what he termed mariposa consciousness. The threaded narrative in the genealogy of Jotería Studies continues to highlight the systematic oppression that inflicts violence onto queer Latinx/a/o people while also holding multiple truths of survival, resistance, and resiliency.

To this extent, the second guideline encompasses the requirement to integrate formative literature and texts by queer Latinx/a/o scholars outside of the field of higher education. Curating an interdisciplinary reading must take place prior to and during the development and execution of the research study. For example, the literature review is one area that should include an analysis of Jotería Studies. Similarly, the way a 
Journal Committed to Social Change on Race and Ethnicity | Volume 7, Issue 1 | 2021

researcher discusses their epistemology, theoretical frameworks, and perspectives should integrate a Jotería Studies genealogy in different capacities, as described later in this manuscript. Doing so opens up the possibility to expand the focus of research and inevitably, practice related to queer Latinx/a/o people in higher education.

\section{Guideline 3: Identifying and Honoring the Epistemological Foundations of Jotería} Studies

In order to mobilize Jotería Studies in qualitative inquiry in education, it is essential that researchers think through how they will situate this framework in a particular epistemology. Specifically, a study's epistemological foundation reflects "the theory of knowledge embedded in the theoretical and thereby in the methodology" (Crotty, 1998, p. 3). For qualitative scholars, a project's epistemology represents the project's philosophical underpinnings and should inform every part of the study design (Bhattacharya, 2017; Jones et al., 2014). Therefore, the question becomes what is the epistemological grounding of jotería?

Given Jotería Studies' genealogy in numerous disciplines like Chicanx/a/o/ and Latinx/a/o Studies, Ethnic Studies, Gender and Sexuality Studies, and Performance Studies (Alvarez Jr. \& Estrada, 2019), Jotería Studies is epistemologically complex and multiplicitous. Specifically, scholars have named that the interconnections of these disciplines contribute to its expansive utility (Madrid, 2018). Namely, we assert that the landscape of Jotería Studies attends to a post structural tradition of deconstruction, showing how identities are fluid and shaped by discourses of power, while at the same time interrogating the material and structural ways systems of power manifest in a way aligning with critical theory (Denzin, 2017; Kincheloe \& McLaren, 2011). In order to 
Journal Committed to Social Change on Race and Ethnicity | Volume 7, Issue 1 | 2021

operate within this space of working with various epistemological groundings, we suggest following the example of a formative thinker, Gloria Anzaldúa.

In particular, Anzaldúa's (1987) work illustrated what it means for individuals like queer Latinx/a/o people to live in different worlds, while at the same time, not feeling like they belong in either - a cognitive tension that she referred to as nepantla. And yet, this position also contributes to a standpoint that is enriched from this position. Relevant to its mobilization in qualitative research, an educational researcher by the name of Abes (2009) envisioned what it means to translate the concept of the borderlands to the inquiry process. Specifically, Abes (2009), in writing about college students, stated that each theoretical perspective and epistemological stance is itself incomplete. To offer a more complex view of how students navigate collegiate environments and how these settings influence them, Abes (2009) suggested that scholars leverage more than one epistemological foundation to shape their studies. It is in this tradition that we recommend that researchers embrace the borderlands, discussing how Jotería Studies functions at the intersections of numerous epistemological frameworks.

From one perspective, Jotería Studies has a strong focus on identity, showcasing how queer Latinx/a/o individuals practice agency and resistance in the face of intersecting oppressive power structures (Tijerina Revilla \& Santillana, 2014). In this vein, Jotería Studies is rooted in a poststructural tradition that discusses ideas of identity, fluidity, and deconstructing meaning. Nevertheless, it is imperative to name that Jotería Studies operates in extension of queer theory. Specifically, scholars have critiqued the overt whiteness that permeates queer theorizing (Hames-García, 2011). Rather than simply examining how people may consciously or unconsciously engage in 
Journal Committed to Social Change on Race and Ethnicity | Volume 7, Issue 1 | 2021

acts that constructs the performance of their identities, Jotería Studies theorists bring attention to how queer Latinx/a/o are agentic in their performances. One must not look further than the work of Muñoz (1999) who presented a theory of disidentifications, detailing how QoC engage in subversive acts that challenge systems of heterosexism, trans oppression, and racism. In higher education, Duran et al. (2019) used disidentifications to present how queer Latino men navigate matters of love when settings perpetuate heterosexism. In this poststructural view, researchers highlight these conscious behaviors that queer Latinx/a/o do in order to further love and empowerment (Calvo-Quíros, 2014; Tijerina Revilla \& Santillana, 2014).

Conversely, Jotería Studies can also be situated under a critical school of thought due to its focus on how structures, policies, and practices function to disenfranchise queer Latinx/a/o individuals. In fact, Jotería Studies has explicit connections to other critical theories such as Critical Race Theory (Hiraldo, 2010; Ladson-Billings \& Tate, 1995; Solórzano, 1997) and Chicana Feminist Epistemology (Bernal, 1998). As a critical project, Jotería Studies exposes how historical and contemporary legacies of oppression function - specifically as it relates to systems like racism, heterosexism, gender oppression, patriarchy, and settler colonialism (Alvarez Jr. \& Estrada, 2019; Hames-García, 2014; Tijerina Revilla \& Santillana, 2014). The task of a critical researcher then becomes identifying these structures and working toward their eventual eradication. Though critical epistemology inherently offers a different working understanding of knowledge and how the world works, we contend that it pairs well with poststructuralism in order to actualize the full potential of Jotería Studies.

Guideline 4: Engaging in Methods that Honor Participants' Epistemological and Ontological Realities 
In alignment with the previous guidelines outlined, using Jotería Studies in qualitative research about queer Latinx/a/o people must engage methods that honor participants' epistemological and ontological ${ }^{1}$ realities. Engaging in methods that deviate from traditional qualitative and mixed-methods such as interviews and/or surveys can expand the ways researchers think about what data is and what it means to collect and analyze certain data. Much of the existing research on queer Latinx/a/o people in higher education has been conducted through semi-structured interviews and mixed-method surveys using different measurement scales. Although the qualitative data collected in these studies adds instrumental scholarship to the field, the methodological tools may limit the potential of critical and in-depth data.

One example of a methodological practice that opens up a critical space for the researcher and participant is the method of pláticas (Fierros \& Delgado Bernal, 2016; Guajardo \& Guajardo, 2013). Pláticas create a culturally congruent and innovative way to engage with queer Latinx/a/o people. As Fierros and Delgado Bernal (2016) described, "Our family pláticas allow us to witness shared memories, experiences, stories, ambiguities, and interpretations that impart us with a knowledge connected to personal, familial, and cultural history" (p. 99). Using pláticas as a research methodology and method coupled with a Jotería and Jotería Studies framework deconstructs the traditional interview process between a researcher and participant and thus allows the creation of collaborative meaning making. The process of pláticas not only become a transformational tool when looking to obtain data but act as an intimate

\footnotetext{
${ }^{1}$ Ontology is defined by many as the questions about existing and what it means to be contrasted to epistemology defined as the nature of knowing (see Jones et al., 2014).
} 
Journal Committed to Social Change on Race and Ethnicity | Volume 7, Issue 1 | 2021

process between the co-constructors (researcher and participant) that creates extensions of ways of knowing and being and are integral to the development of research (Fierros \& Delgado Bernal, 2016, p. 101). Additionally, there is an intentional purpose to incorporating the pláticas as they "are different from interviews because they are reciprocal exchanges in which participants are co-collaborators and co-creators in the production of knowledge and the research process" (Garcia \& Mireles-Rios, 2019, p. 7). By centering the queer Latinx/a/o subject as the arbitor of knowledge (Pérez, 2014b), not only do pláticas motivate the participant to engage and co-create knowledge, but it acknowledges and affirms a sense of agency in who they are.

In addition to pláticas, art can be a symbolic method that engages in a project of recovering and remembering for and of queer Latinx/a/o people. Art has a way of leaving interpretation as subjective and as a way for individuals to express themselves. For example, Pérez (2014a) analyzed the symbolism behind the use of the mariposa, "butterfly", in what is deemed as queer art. He articulates the notion of using the mariposa as a mariposa consciousness which he defines as "part of an ongoing decolonial project in which several writers, artists, and scholars have engaged to facilitate awareness of the social locations, social relations, and history of the mariposa subject, with several parallels and links to Jotería consciousness" (Pérez, 2014a, p. 101). The symbolism of the mariposa captures the agency asserted by queer Latinx/a/o people through the continual survival of intersectional struggles of oppression. Consequently, the way data is collected is important to honoring the knowledge production of queer Latinx/a/o people. 
Journal Committed to Social Change on Race and Ethnicity | Volume 7, Issue 1 | 2021

\section{Guideline 5: Attending to Jotería Studies in the Analytical Process}

To actualize the potential of Jotería Studies requires that scholars not only reflect on how they attend to this framework in their data collection but also how they can attend to its potential in the analytical process. Given the complexities that Jotería studies offers to examine how power, oppression, and agentic behaviors manifest for queer Latinx/a/o communities (Alvarez Jr. \& Estrada, 2019; Hames-García, 2014; Tijerina Revilla \& Santillana, 2014), researchers must also lean into these intricacies in their analysis. Guided by Abes' (2009) work on the theoretical borderlands, we imagine one way that scholars can honor Jotería Studies as they analyze the stories of participants.

First, we follow the suggestion of Abes (2009) when she wrote that existing in the theoretical borderlands includes seeing data from multiple perspectives. In the case of Jotería Studies, those conducting qualitative studies can read participants' narratives from different epistemological perspectives. Above, we contended that Jotería Studies lies at the intersections of poststructural and critical paradigms, which in turn should inform the analytical process. Consequently, we envision it being useful to read data numerous times from these vantage points. One may begin by reading data with a lens stemming from the critical traditions of Critical Race Theory in education (Hiraldo, 2010; Ladson-Billings \& Tate, 1995; Solórzano, 1997) and Chicana Feminist Epistemology (Bernal, 1998) that Jotería Studies engages. In this critical reading, scholars may be particularly attuned to the policies, structures, environments, and contexts that perpetuate heterosexism, trans oppression, and racism that in turn structures the lives of queer Latinx/a/o individuals. Following this reading, it would be useful to then 
Journal Committed to Social Change on Race and Ethnicity | Volume 7, Issue 1 | 2021

approach the data informed by poststructural thought, as Jotería Studies also resisted the whiteness present in queer theory (Hames-García, 2011; Pérez, 2014b). In this reading, researchers interrogate how people's identities are fluid, dynamic, and responsive to systemic oppression. Finally, scholars can consider how these readings connect to one another. Of note, they should wrestle with the convergences and divergences that exist in these readings in order to provide interpretations of the data that are nuanced.

Following these readings, we encourage researchers to get closer to the data. Rather than viewing it from a macro-perspective, scholars should see the different discourses that are present in participants' experiences given Jotería Studies' interest in linguistics (Cashman, 2019). What are individuals saying? What are they not? How do they use language that highlights their agency? How do they implicate systems of oppression? Importantly, scholars should do this while allowing for the multiple meanings that exist in their qualitative data. Therefore, we recommend against breaking data down into codes that suggest a singular interpretation (Jackson \& Mazzei, 2013), instead opening up the different ways that participants are signaling their realities. Connected to this point, as researchers move back from the micro- (i.e., reading closely to the data) to the macro- (offering insights that translate across participants), they must do so in a way that embraces the messiness that transpires from living life in the borderlands (Anzaldúa, 1987). The stories of queer Latinx/a/o people are complex and multifaceted; thus, the researcher must restrain themselves from providing a onedimensional way of viewing narratives, where a "true" reading exists. This act may look 
Journal Committed to Social Change on Race and Ethnicity | Volume 7, Issue 1 | 2021

like moving away from themes that are static, but instead offering up possibilities of reading participants' stories.

Lastly, we assert that engaging Jotería Studies involves researchers rethinking how they engage participants in the analytical process. Rather than simply asking participants in a member-checking process, a common measure of trustworthiness (see Jones et al., 2014), scholars should consider involving individuals in the analytical process itself. That is because engaging member- checking at the end of a study limits the epistemic advantage that participants hold, as the researcher primarily relies on their interpretations throughout and constrains the opportunity for participant input (Jones et al., 2014). Instead, we believe scholars should consider breaking down the researcher-participant barrier by co-constructing ideas about patterns that are emerging in a particular study. For instance, a researcher could hold individual interviews or focus groups to offer what they are seeing in the data, but actively ask for participants' responses on how they either affirm these perspectives or do not view themselves reflected in these thoughts. Another consideration that researchers must account for is inquiry competence and relational competence as part of the trustworthiness (Jones et al., 2014), to ask themselves critical questions of where the data leads them and contemplating their positionality within the research study. Such acts attend to Jotería Studies' focus on empowerment (Tijerina Revilla \& Santillana, 2014). In essence, the researcher in this instance is creating the space for participants to practice their agency and to center their knowledge. 
Journal Committed to Social Change on Race and Ethnicity | Volume 7, Issue 1 | 2021

\section{Guideline 6: Engaging an Oppositional Consciousness in Mobilizing a Jotería Praxis}

An area that necessitates further examination is the use of Jotería Studies to inform practice in higher education. Epistemologies rooted in queerness elucidate an area that can contribute to an intentional use of research and theory to inform practice (Lange et al., 2019). It is not merely enough for researchers to acknowledge Queers of Color within the structures of oppression, but there must be a responsibility to provide ways of engaging a praxis rooted in liberation. Specifically, theorizing from the margins of race, ethnicity, gender, and sexuality necessitates a consciousness of resistance or an oppositional consciousness. Sandoval (2000) described oppositional consciousness as "a set of critical points within which individuals and groups seeking to transform dominant and oppressive powers can constitute themselves as resistant and oppositional citizen-subjects" (p. 54). Jotería Studies is rooted in resistance of heteronormativity, racism, sexism, and classism, among other forms of structural oppression (Bañales, 2014). Because the history of Jotería Studies centers community through art, activism, and scholarship (Tijerina Revilla, 2014), it is imperative that scholars who use Jotería Studies account for community-centered practices informed by an oppositional consciousness.

Higher education research often aims to intentionally inform the work of practitioners and administrators in postsecondary education settings; therefore, using Jotería Studies leverages critical sites of knowledge production and practice. Researchers must challenge the use of Jotería Studies as a simple prescription of queer Latinx/a/o identities in higher education practice and move towards a continual 
Journal Committed to Social Change on Race and Ethnicity | Volume 7, Issue 1 | 2021

resistance of engrained heteronormative and racist structures of how practitioners engage queer Latinx/a/o people in higher education. Orozco (2017) posited using practices rooted in "honoring the lived experience of consistently being in borderlands, navigating in and out of spaces that speak truth to reality" (p. 6). Shifting praxis to engage queer Latinx/a/o people's embodied knowledge and realities propels the possibility for a shift in material responses for queer Latinx/a/o people.

Several examples showcase the ways oppositional consciousness informs a Jotería praxis through individual and collective resistance and queer kinships. Tijerina Revilla $(2004,2010)$ highlighted the way Chicana and Latina college students negotiate and engage with issues of gender and sexuality through individual and collective resistance. Similarly, Duran et al. (2019) examined the ways gay Latino college men push back against heteronormative ideals of love and build queer resistance and survival. These are two examples that provide an opportunity for practitioners in building spaces of resistance for queer Latinx/a/o college students. Consequently, the way that community and activism become central to the practice of Jotería Studies is a condition for a Jotería praxis. As such, research and theory should expand to imagine how a Jotería praxis manifest outside of normative co-curricular spaces such as cultural centers and academic spaces (Lange et al., 2019).

\section{Future Directions for Jotería Studies Research in Higher Education}

In outlining how qualitative researchers can mobilize Jotería Studies in the study of higher education, we also noticed gaps in the postsecondary literature on queer Latinx/a/o individuals that scholars using this framework can attend to in their work. Specifically, researchers can be more attentive to who is represented in the scholarship, 
Journal Committed to Social Change on Race and Ethnicity | Volume 7, Issue 1 | 2021

as well as which contexts have historically been investigated. To begin, one more prominent trend that is present in higher education research is the focus on undergraduate students as the population of interest. Namely, in research on queer Latinx/a/o people, studies have only examined the issues and successes that undergraduate students face (Duran et al., 2020). Although it is imperative to center undergraduate students in research, the shortage of literature on graduate students, faculty, and staff warrants attention. Namely, Queer Faculty and Staff of Color face unique challenges by virtue of their positions at colleges and universities (Aguilar \& Johnson, 2017) with the same being reasonably true for graduate students. It is our belief that Jotería Studies is a valuable framework to understand how queer Latinx/a/o graduate students, together with staff and faculty, move through higher education institutions. The reason being is that Jotería Studies can expose how institutional structures like evaluation and promotion policies constrain those at the intersections of queerness and Latinx/a/o identities, while at the same time, illustrating the ways that individuals resist these norms. Specifically, Jotería Studies can be effective in addressing how academic standards are rooted in racist, heterosexist, and transphobic beliefs, which affects queer Latinx/a/o individuals uniquely. These types of studies can contribute to the limited perspectives on how individuals employ Jotería in their pedagogy (Alvarez, 2014) and expand beyond the dynamics encountered in the classroom environment.

Beyond the potential to shed a light on populations beyond undergraduate students, scholars can leverage Jotería Studies to reimagine how queer Latinx/a/o people negotiate their identities in different contexts. One example of this potential area 
Journal Committed to Social Change on Race and Ethnicity | Volume 7, Issue 1 | 2021

of exploration involves how queer Latinx/a/o individuals perceive and engage with groups on campus that only center one of their minoritized identities. In the broader scholarship on Queer Students of Color, researchers have brought to light the oppressive interactions that they can have in LGBTQ+ groups or Communities of Color by virtue of them perpetuating within-group marginalization (Duran, 2019). The question then becomes how are groups on campuses mindful of multiple minoritized identities and how does this influence queer Latinx/a/o people? This is important to answer given the ways that researchers have documented how queer Latinx/a/o individuals are rendered invisible or othered based on the rigid gender/sexual norms present in society overall, but also in Latinx/a/o communities specifically (e.g., Duran \& Pérez, 2017; Eaton \& Rios, 2017; Peña-Talamantes, 2013a). Therefore, Jotería Studies could be a framework that can expose how Latinx/a/o student organizations or academic programs themselves also further anti-queer rhetoric. However, this phenomenon is not specific to Latinx/a/o communities themselves. LGBTQ+ student organizations and resource centers have also been the subject of critique for being rooted in white norms (Vaccaro \& Mena, 2011). And yet, it is not clear how these cultures may disproportionately affect Latinx/a/o populations. Because Jotería Studies' foundations in critical theory helps illustrate how systems of oppression impacts queer Latinx/a/o individuals (Alvarez Jr. \& Estrada, 2019; Hames-García, 2014; Tijerina Revilla \& Santillana, 2014), it can be employed to examine within-group marginalization present in queer spaces or Latinx/a/o communities at colleges and universities. As highlighted above though, these studies should simultaneously foreground how queer Latinx/a/o people are agentic in these spaces. 
Journal Committed to Social Change on Race and Ethnicity | Volume 7, Issue 1 | 2021

Additionally, we argue that researchers can utilize Jotería Studies to understand how queer Latinx/a/o people access and navigate numerous contexts in and outside of higher education. For example, Peña-Talamantes' (2013b) study on gay/lesbian Latino students showed that these individuals are negotiating their realities both on campus, but also back at their home community. What Peña-Talamantes (2013b) work revealed is that queer Latinx/a/o students are balancing complex situations and environments not always explicitly occurring at their postsecondary institutions. Therefore, Jotería Studies can assist in comprehending what this means for queer Latinx/a/o people and how they create counterspaces in different environments. How do queer Latinx/a/o people discuss the concept of college-going? In what ways are queer Latinx/a/o individuals connecting to local communities to survive and thrive when they access higher education? How do queer Latinx/a/o people use their relationships from back home to maintain resilience? These are all questions that can be answered using Jotería Studies as a framework. Although these directions are by no means exhaustive, they represent starting places for researchers to begin in the service of incorporating Jotería in postsecondary scholarship.

\section{Conclusion}

The emergence of the field of Jotería Studies is an opportunity for research on queer Latinx/a/o people in higher education (Duran et al., 2020). The utility of Jotería Studies can help to inform the way postsecondary scholars conceptualize and execute research that propels new understandings on queer Latinx/a/o people and the practices that are often missing for this population in higher education. Researchers who intend to use Jotería Studies must do so with care and intentionality to account for the history of 
Journal Committed to Social Change on Race and Ethnicity | Volume 7, Issue 1 | 2021

this work. Several scholars of Jotería Studies articulate different ways of engaging it in their own research (Bañales, 2014; Calvo-Quíros, 2014; Pérez, 2014a; Tijerina Revilla \& Santillana, 2014), and as such, we hope to emphasize that there does not exist rigid tenets or steps on what is required for researchers to use Jotería Studies. Instead, we hope that these guidelines help to pave the way for scholars to interrogate race, ethnicity, sexuality, and gender for queer Latinx/a/o people, together with helping build collaborative relationships between the field of Jotería Studies and higher education. 
Journal Committed to Social Change on Race and Ethnicity | Volume 7, Issue 1 | 2021

\section{References}

Abes, E. S. (2009). Theoretical borderlands: Using multiple theoretical perspectives to challenge inequitable power structures in student development theory. Journal of College Student Development, 50(2), 141-156.

Aguilar, D., \& Johnson, J. M. (2017). Queer Faculty and Staff of Color: Experiences and expectations. In J. M. Johnson \& G. Javier (Eds.), Queer People of Color in higher education (pp. 57-72). Information Age Publishing.

Aguilar-Hernández, J. M. (2020). Queering critical race pedagogy: Reflections of disrupting erasure while centering intersectionality. International Journal of Qualitative Studies in Education, 33(6), 679-694.

Alvarez, E. F., Jr. (2014). Jotería pedagogy, SWAPA, and Sandovalian approaches to liberation. Aztlán: A Journal of Chicano Studies, 39(1), 215-227.

Alvarez Jr., E. \& Estrada, J. (2019). Jotería studies. In H. Chang (Ed.), Global encyclopedia of lesbian, gay, bisexual, transgender, and queer (LGBTQ) history (pp. 863-867). Charles Scribner \& Sons.

Anzaldúa, G. E. (1987). Borderlands/La frontera: The new mestiza. Aunt Lute Books.

Bañales, X. (2014). Jotería: A decolonizing political project. Aztlán: A Journal of Chicano Studies, 39(1), 155-165.

Bernal, D. D. (1998). Using a Chicana feminist epistemology in educational research. Harvard Educational Review, 68(4), 555-583.

Bhattacharya, K. (2017). Fundamentals of qualitative research: A practical guide. Routledge.

Calvo-Quíros, W. A. (2014). The aesthetics of healing and love: An epistemic genealogy of Jota/o aesthetic traditions. Aztlán: A Journal of Chicano Studies, 39(1), 181194.

Cashman, H. R. (2019). What Phoenix' joteria is saying: Identity, normativity, resistance. Language in Society, 48(4), 519-539.

Chan, J. (2017). "Am I masculine enough?": Queer Filipino college men and masculinity. Journal of Student Affairs Research and Practice, 54, 82-94.

Cisneros, J. \& Gutierrez, J. (2018). "What does it mean to be undocuqueer?": Exploring (il)Legibility within the intersection of gender, sexuality, and immigration status. QED: A Journal in GLBTQ Worldmaking, 5(1), 84-102.

Cisneros, J. \& Bracho, C. (2019). Coming out of the shadows and the closet: Visibility schemas among undocuqueeer immigrants. Journal of Homosexuality, 66(6), 715-734.

Collins, P. H. (1991). Black feminist thought: Knowledge, consciousness, and the politics of empowerment. Routledge.

Crenshaw, K. (1989). Demarginalizing the intersection of race and sex: A Black feminist Critique of antidiscrimination doctrine, feminist theory, and antiracist politics. University of Chicago Legal Forum, 1989(8), 139-167.

Crotty, M. (1998). The foundations of social research: Meaning and perspective in the research process. Sage.

Denzin, N. K. (2017). Critical qualitative inquiry. Qualitative Inquiry, 23(1), 8-16. 
Journal Committed to Social Change on Race and Ethnicity | Volume 7, Issue 1 | 2021

Duran, A. (2019). Queer and of color: A systematic literature review on queer students of color in higher education scholarship. Journal of Diversity in Higher Education, 12(4), 390-400.

Duran, A. \& Jones, S. R. (2020). Complicating identity exploration: An intersectional grounded theory centering Queer Students of Color at historically white institutions. Journal of College Student Development, 61(3), 281-298.

Duran, A., \& Pérez, D., II. (2017). Queering la familia: A phenomenological study reconceptualizing familial capital for queer Latino men. Journal of College Student Development, 58(8), 1149-1165.

Duran, A., \& Pérez, D., II. (2019). The multiple roles of chosen familia: Examining the interconnections of queer Latino men's community cultural wealth. International Journal of Qualitative Studies in Education, 32(1), 67-84.

Duran, A., Orozco, R., \& Gonzalez, S. (2020). Imagining the future of jotería studies as a framework in the field of higher education. Association of Mexican American Educators Journal, 14(2), 67-86.

Duran, A., Rodriguez, F., \& Patrón, O. E. (2019). Queer love in the lives of gay Latino men in college. International Journal of Qualitative Studies in Education. Advance online publication. https://doi.org/10.1080/09518398.2019.1687957

Eaton, A. A., \& Rios, D. (2017). Social challenges faced by queer Latino college men: Navigating negative responses to coming out in a double minority sample of emerging adults. Cultural Diversity and Ethnic Minority Psychology, 23(4), 457467.

Ferguson, R. A. (2004). Aberrations in Black: Toward a queer of color critique. University of Minnesota Press.

Fierros, C. O., \& Delgado Bernal, D. (2016). Vamos a platicar: The contours of pláticas as Chicana/Latina feminist methodology. Chicana/Latina Studies, 15(2), 98-121.

Garcia, N. M., \& Mireles-Rios, R. (2019). "You were going to go to college": the role of Chicano fathers' involvement in Chicana daughters' college choice. American Educational Research Journal. Advance online publication. https://doi.org/10.3102/0002831219892004

Guajardo, F. \& Guajardo, M. (2013). The power of plática. Reflections, 13(1), 159-164. Hames-García, M. (2011). Queer theory revisited. In Michael Hames-García \& Ernesto Javier Martínez (Eds.), Gay Latino studies: A critical reader (pp. 19-45). Duke University Press.

Hames-García, M. (2014). Jotería Studies, or the political is personal. Aztlán: A Journal of Chicano Studies, 39(1), 135-141.

Hames-García, M. \& Martínez, E. J. (Eds.). (2011). Gay Latino studies: A critical reader. Duke University Press.

Hiraldo, P. (2010). The role of critical race theory in higher education. The Vermont Connection, 31(1), 53-59.

Jackson, A. Y., \& Mazzei, L. A. (2013). Plugging one text into another: Thinking with theory in qualitative research. Qualitative Inquiry, 19(4), 261-271.

Johnson, E. P. (2001). "Quare" studies, or (almost) everything I know about queer studies I learned from my grandmother. Text and Performance Quarterly, 21(1), $1-25$. 
Journal Committed to Social Change on Race and Ethnicity | Volume 7, Issue 1 | 2021

Johnson, A. A. \& Quaye, S. J. (2017). Queering Black racial identity development. Journal of College Student Development, 58(8), 1135-1148.

Johnson, J. M. \& Javier, G. (Eds.) (2017). Queer People of Color in higher education. Information Age Publishing.

Jones, S. R., Torres, V., \& Arminio, J. (2014). Negotiating the complexities of qualitative research in higher education: Fundamental elements and issues (2nd ed.). Routledge.

Kincheloe, J. L., \& McLaren, P. (2011). Rethinking critical theory and qualitative research. In k. hayes, S. R. Steinberg, \& K. Tobin (Eds.), Key works in critical pedagogy (pp. 285-326). Sense Publishers.

King, A. R. (2011). Environmental influences on the development of female college students who identify as multiracial/biracial-bisexual/pansexual. Journal of College Student Development, 52(4), 440-455.

Ladson-Billings, G., \& Tate, W. (1995). Toward a critical race theory of education. Teachers College Record, 97(1), 47-68.

Lange, A., Duran, A., \& Jackson, R. (2019). The state of LGBT and queer research in higher education revisited: Current academic houses and future possibilities. Journal of College Student Development, 60(5), 511-526.

Lopez, A. P. (2018). The X in Latinx is a wound, Not a trend. https://www.colorbloq.org/the-x-in-latinx-is-a-wound-not-a-trend

Lorde, A. (2007). Sister outsider: Essays and speeches. Crossing Press.

Madrid, A. L. (2018). Secreto a voces: Excess, performance, and jotería in Juan Gabriel's vocality. GLQ: A Journal of Lesbian and Gay Studies, 24(1), 85-111.

McGuire, K. M., Cisneros, J., \& McGuire, T. D. (2017). Intersections at a (heteronormative) crossroad: Gender and sexuality among Black students' spiritual-and-religious narratives. Journal of College Student Development, 58(2), 175-197.

Means, D. R. (2017). "Quaring" spirituality: The spiritual counterstories and spaces of Black gay and bisexual male college students. Journal of College Student Development, 58(2), 229-246.

Means, D. R., Collier, J., Bazemore-James, C., Williams, B. M., Coleman, R., \& Wadley, B. A. (2018). "Keep your spirit aligned": A case study on Black lesbian, gay, bisexual, and queer students defining and practicing spirituality. Journal of College Student Development, 59(5), 618-623.

Milian, C. (2020). LatinX. University of Minnesota Press.

Miller, R. A. \& Vaccaro, A. (2016). Queer student leaders of color: Leadership as authentic, collaborative, culturally competent. Journal of Student Affairs Research and Practice, 53(1), 39-50.

Misawa, M. (2010). Racist and homophobic bullying in adulthood: Narratives of gay men of color in higher education. New Horizons in Adult Education and Human Resource Development, 24(1), 7-23.

Moradi, B. \& Grzanka, P.R. (2017). Using intersectionality responsibly: Toward critical epistemology, structural analysis, and social justice activism. Journal of Counseling Psychology, 64(5), 500-513.

Moraga, C. \& Anzaldúa, G. E. (1981). This bridge called my back: Writings by radical women of color. Kitchen Table--Women of Color Press. 
Journal Committed to Social Change on Race and Ethnicity | Volume 7, Issue 1 | 2021

Moraga, C. (1983). Loving in the war years: Lo que nunca paso por sus labios (2nd ed.). South End Press.

Muñoz, J. E. (1999). Disidentifications: Queers of color and the performance of politics. University of Minnesota Press.

Muñoz, J. E. (2003). Cruising utopia: The then and there of queer futurity. NYU Press.

Núñez, A.-M. (2014). Advancing an intersectionality framework in higher education: Power and Latino postsecondary opportunity. In M. B. Paulsen (Ed.), Higher education: Handbook of theory and research (Vol. 29, pp. 33-92). Springer.

Orozco, R.C. (2017). Fostering nepantla practice; Fomentando la practica de nepantla. NASPA Gender and Sexuality Knowledge Community White Paper. Spring. 5-7.

Orozco, R. C. \& Pérez-Felkner, L. (2018). Ni de aquí, ni de allá: Conceptualizing the self-authorship of gay Latino college men using conocimiento. Journal of Latinos in Education, 17(4), 386-394.

Patton, L. D. \& Simmons, S. L. (2008). Exploring complexities of multiple identities of lesbians in a Black college environment. The Negro Educational Review, 59(3-4), 197-237.

Peña-Talamantes, A. E. (2013a). "Defining machismo, no es siempre lo mismo": Latino sexual minorities machoflexible identities in higher education. Culture, Society \& Masculinities, 5(2), 166-178.

Peña-Talamantes, A. E. (2013b). Empowering the self, creating worlds: Lesbian and gay Latina/o college students' identity negotiation in figured worlds. Journal of College Student Development, 54(3), 267-282.

Pérez, D. (2014a). Toward a mariposa consciousness: Reimagining queer Chicano and Latino identities. Aztlán: A Journal of Chicano Studies, 39(1), 95-127.

Pérez, D. (2014b). Jotería epistemologies: Mapping a research agenda, unearthing a lost heritage, and building. Aztlán: A Journal of Chicano Studies, 39(2), 143-154.

Rios, D., \& Eaton, A. (2016). Perceived social support in the lives of gay, bisexual and queer Hispanic college men. Culture, Health \& Sexuality, 18(10), 1093-1106.

Rodríguez, J. M. (2003). Queer Latinidad: Identity, practices, discursive spaces. New York University Press.

Salinas Jr., C. (2020). The complexity of the " $x$ " in Latinx: How Latinx/a/o students relate to, identify with, and understand the term Latinx. Journal of Hispanic Higher Education, 19(2), 149-168.

Salinas Jr., C. \& Lozano, A. (2019). Mapping and recontextualizing the term Latinx: An environmental scanning in higher education. Journal of Latinos and Education, 18(19), 302-215.

Sandoval, C. (2000). Methodology of the oppressed. University of Minnesota Press.

Solórzano, D. G. (1997). Images and words that wound: Critical race theory, racial stereotyping, and teacher education. Teacher Education Quarterly, 24(3), 5-19.

Squire, D. D. \& Mobley, S. D. (2015). Negotiating race and sexual orientation in the college choice process of Black gay males. The Urban Review, 47, 466-491.

Tijerina Revilla, A. (2009). Are all raza womyn queer? An exploration of sexual identities in a Chicana/Latina Student organization. NWSA Journal, 21, 46-62.

Tijerina Revilla, A. (2010). Raza womyn-Making it safe to be queer: Student organizations as retention tools in higher education. Black Women, Gender and Families, 4(1), 37-61. 
Journal Committed to Social Change on Race and Ethnicity | Volume 7, Issue 1 | 2021

Tijerina Revilla, A. \& Santillana, J. M. (2014). Jotería identity and consciousness. Aztlán: A Journal of Chicano Studies, 39(1), 167-179.

Vaccaro, A., \& Mena, J. A. (2011). It's not burnout, it's more: Queer College Activists of Color and mental health. Journal of Gay \& Lesbian Mental Health, 15(4), 339367. 